原子炉用ジルコニウ・ムの溶接

橋 本 達 哉*

Welding of Zirconium

By Tatsuya HASHIMOTO

The most important problem in welding of zirconium is the subject of inert gas shielding. Weld is often contaminated by atmosphere during the welding. But a proper shielding can prevent from the weld from embrittlement and deterioration of corrosion resistance of weld caused by atmospheric contamination. The best way of shielding is to use the inert gas or vacuum chamber. But an improved shielding method being applied here, even in atmospheric environment, satisfiable weld can be obtained.

Generally, zirconium alloy has excellent weldability and practically ductile and corrosion resistant weld can be easily obtained without porosity nor crack.

ジルコニウムにはすぐれた耐食性があり，そのうえ 熱中性子の吸収が少ないので，燃料要素の被覆材その 他に用いられるほか，化学工業用耐食金属として貫重 なるのと考えられている。

ジルカロイ合金は原子师用として開発されたもの
で，チッ素の含有量が少なく、とくにハフニウムを含 まないジルニウム・スポンジを地金に使っている。 この原子炉用ジルコニウム・スポンシの成分を第 1 表 に示してある。

第 1 表 AEC 規格によるジルコニウムの中の不純物の制限量 (ppm)

第エタ゚ループ

\begin{tabular}{|c|c|c|c|c|c|c|c|c|c|c|c|c|c|c|c|c|c|}
\hline 元 菜 名 & Al & B & $\mathrm{Cl}$ & $\mathrm{CI}_{\mathrm{I}}$ & Co & $\mathrm{Hf}$ & $\mathrm{Fe}$ & $\mathrm{Pb}$ & $\mathrm{Mg}$ & $\mathrm{Mn}$ & $\mathrm{Ni}$ & $\mathrm{N}_{2}$ & $\mathrm{O}_{2}$ & $\mathrm{Si}$ & $\mathrm{Ti}$ & V & プリネ \\
\hline 動 限 界 & 300 & 1.0 & & 400 & & 400 & & & 1000 & 200 & 280 & 200 & 800 & 400 & 200 & 200 & \\
\hline \%卜平均 & 75 & 0.5 & 1300 & 200 & 20 & 100 & 1500 & 100 & 600 & 50 & 70 & 50 & 1400 & 100 & 50 & 50 & 150 \\
\hline
\end{tabular}

第 2 グループ

\begin{tabular}{c|c|c|c|c|c|r|r|r|r|r|r}
\hline 元 素 名 & $\mathrm{Cb}$ & $\mathrm{Ca}$ & $\mathrm{C}$ & $\mathrm{Cu}$ & $\mathrm{Li}$ & $\mathrm{Mo}$ & $\mathrm{P}$ & 希土類 & $\mathrm{Na}$ & $\mathrm{W}$ & $\mathrm{Zn}$ \\
\hline 口ット平均 & 0.3 & 30 & 500 & 50 & 1.0 & 50 & 100 & 15 & 50 & 50 & 100 \\
\hline
\end{tabular}

また，原子炉用シルコニウム合金には現在第 2 表の ようなすのがある。ジルカロイー2 む合金て，原子炉用合金としてはもっとる有名であ る。

ジルコニウムは比重 $6.5 て ゙$ 鋼より中や軽く $1,855^{\circ} \mathrm{C}$ という高融点をるら，チタンと同粎に室温から $862^{\circ} \mathrm{C}$ まで稠密六方晶相 $(\alpha$ 相 $)$ で, $862^{\circ} \mathrm{C}$ 以上では体心立方
晶 $(\beta$ 相)である。高温ではきわめて活性であって大気 と反応する。

ジルコニウムはすぐれた正性と強さをすち，加工が 容易である。溶接中，大気による污染を防ぐ配慮の必 要であることを除けば，溶接性は比較的良好である。

* 金属材料技術研究所 (National Res. Inst. for Metals) 
第 2 表原子师用ジルコニウム合金

\begin{tabular}{|c|c|c|c|c|c|c|c|}
\hline \multirow{2}{*}{ 合 金 名 } & \multicolumn{3}{|c|}{ 化 } & \multicolumn{3}{|c|}{ 分 } & \multirow[b]{2}{*}{ Mo } \\
\hline & $\mathrm{Sn}$ & $\mathrm{Fe}$ & $\mathrm{Ni}$ & $\mathrm{Cr}$ & $\mathrm{Nb}$ & $\mathrm{Cu}$ & \\
\hline ジルカロイ -2 & $1.2 \sim 1.7$ & $0.07 \sim 0.2$ & $0.03 \sim 0.08$ & $0.05 \sim 0.15$ & & & \\
\hline ジルカイ -3 & $0.2 \sim 0.3$ & $0.2 \sim 0.3$ & 0.05 & 0.05 & & & \\
\hline ジルカロイ -4 & $1.2 \sim 1.7$ & $0.12 \sim 0.18$ & & $0.05 \sim 0.15$ & & & \\
\hline オビナイトー5 & $0.1 \sim 0.3$ & $0.1 \sim 0.3$ & $0.1 \sim 0.3$ & & $0.1 \sim 0.3$ & & \\
\hline オゼナイト-0.5 & 0.2 & 0.1 & 0.1 & & 0.1 & & \\
\hline ATR & & & & & & 0.5 & 0.5 \\
\hline $\mathrm{Zr}-\mathrm{Nb}$ 合金 & & & & & 15 & $\mathrm{Pd}$ & Mo \\
\hline
\end{tabular}

\section{I 。溶接上の諸問題}

溶接に执いてまず第 1 に注意すべき点は，大気を完 全にシールドして溶接せねばならぬことである。第1 〜4四はイナートガスフーク溶接において，フルゴン 雾囲気中に空気などを混入してその純度を变化させ て，溶接金属中のガス量と延性を調べたものである が，溶接部は不純物を含有すると極度に延性を失う。 また耐食性あるいは加工性も損なわれる。したがって 溶接施工では，大気による污染を極力防止するため， シールドを完全にし，特別な場合を除いて，溶接部が 均一かつ急速に冷却するような溶接条件を採用して大 気との接触時間をできるだけ短くするのが得策であ る。ふつう大気の污染をうけると溶接部は着色し，そ の程度に応じて薄紫色，黒灰色，灰白色を呈する。

また合金元素が加わると，その溶接部はやはり硬化

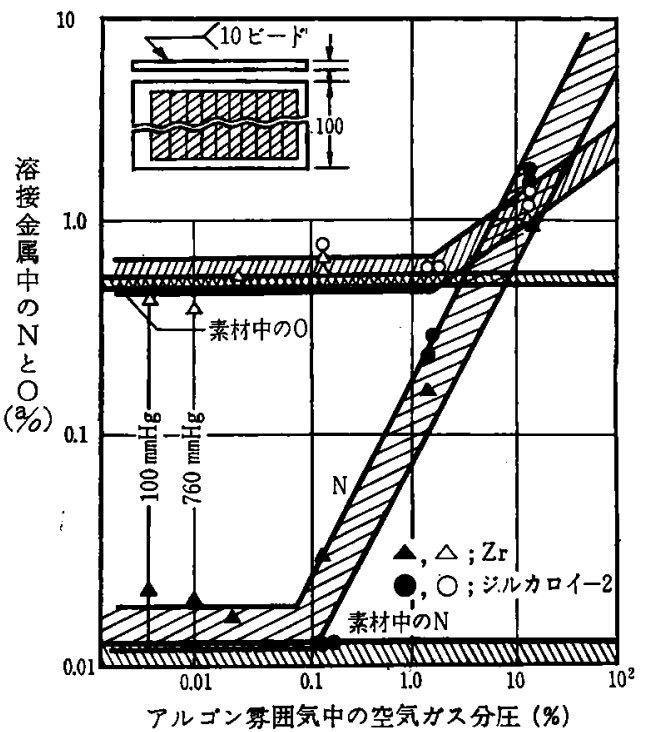

第 1 图溶接票囲気中の空気の分圧 $\left(P_{\mathrm{ulr}}\right)$ と溶接 金属中の[N],〔O]との関係(TIG)

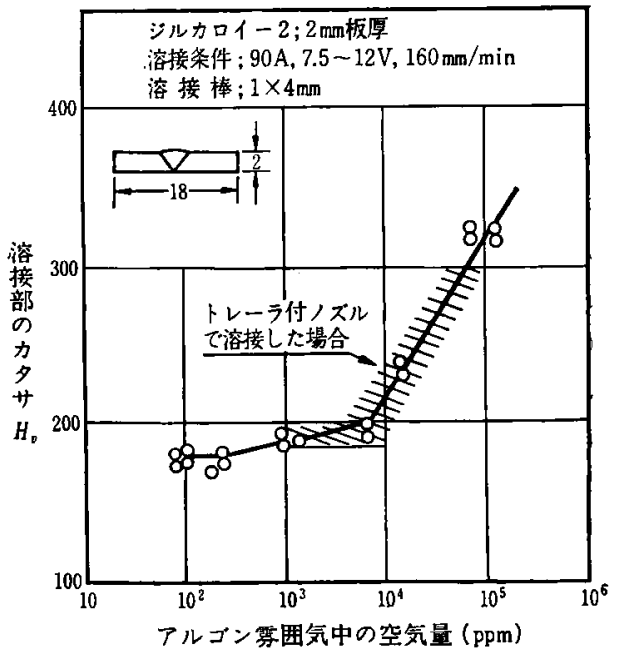

第 2 図空気量と溶接部のカタサとの関係(TIG)

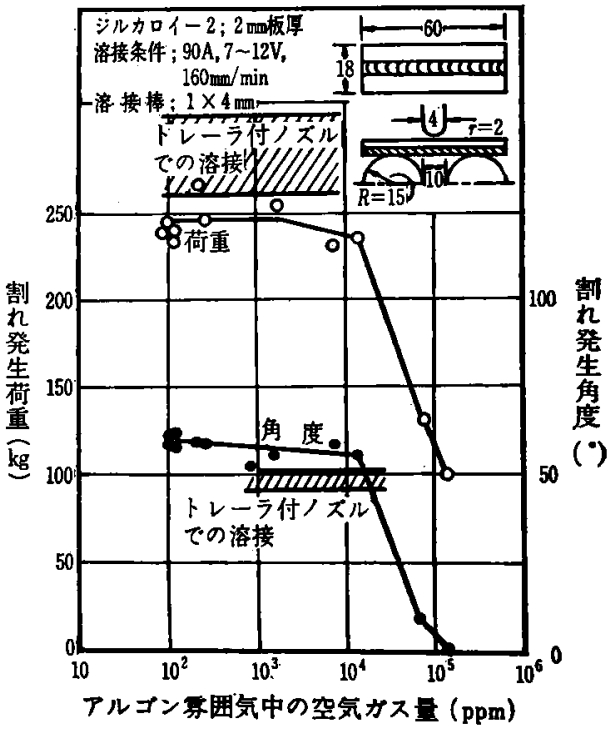

第 3 図空気ガス量と継手の曲げ特性(TIG)。 


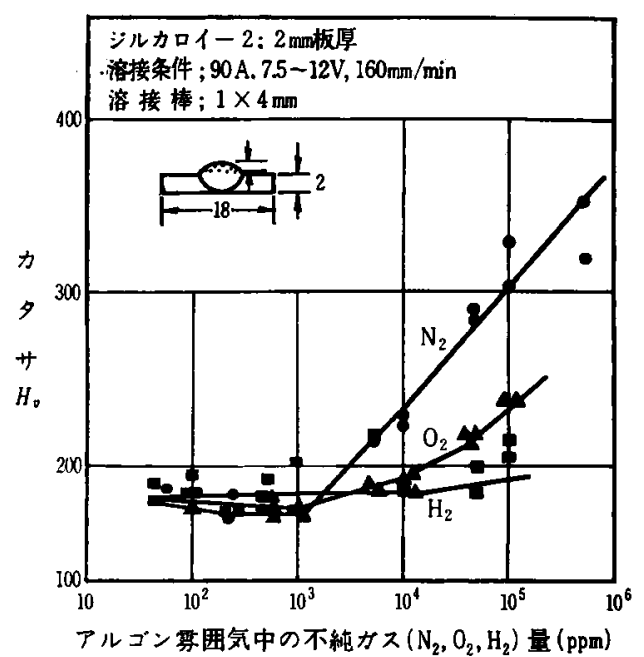

第 4 図不純単独ガス $\left(\mathrm{N}_{2}, \mathrm{O}_{2}, \mathrm{H}_{2}\right)$ 量と溶接部の 最高力タサとの関係(TIG)

あるいはぜい化して溶接欠陷を生じやすく，溶接部の 延性が低下するため溶接が困難といわれる。したがっ て，溶接中の冷却条件あるいは溶接後の熱処理など， 溶接に付帯した諸問題が扣きるものと考学られる。し かし、ジルカロイ合金の溶接にはさほど困難はない。 ただ溶接部の冷却速度が遅かったりあるいは多層溶 接の場合などに化合物が析出し，ぜい化することがあ るといわれている。

\section{II . 溶 接 法}

これらの金属に対して用いられる溶接法には，大体 つぎのようなものがある。

\section{1. イナートカススアーク溶接法}

溶接個所にイナートガスを噴射しながらアーク溶接 する方法で，第 5 図のように電極にタングステンを用 いる TIG 法と, 溶接棒を電極とする MIG 法とがあ る。ガスはかが国ではフルゴンで市販の高純度アルゴ ン $(99.99 \%$ 以上) が用いられる。この方法はアルミニ

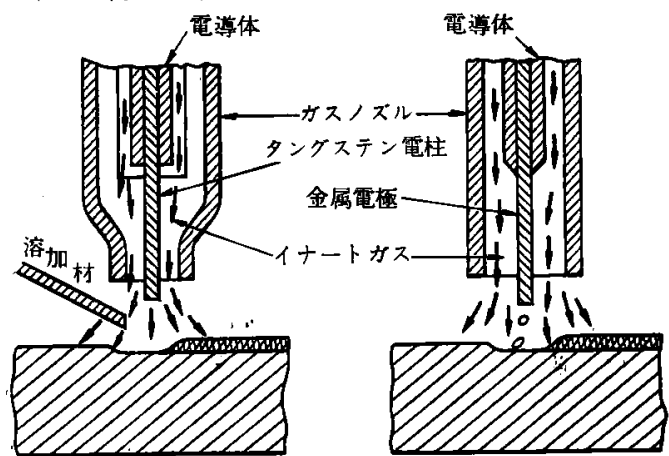

(TIG)
(MIG)
第 5 図イナートガスアーク溶接の 2 型式
ウム,ステンレス鋼などの溶接に用いられて良好な結 果が得られ, 現在活性材料の溶接法としてもっとも普 及している方法である。従来の方法だけでは不充分な 金属に対しては, シールドをいっそう完全にするため 種々の土夫がなされ，ふつうのトーチに補助ノズルを 取り付けたり，溶接部の裏側からもガスを送給する。 また，あらかしめ高真空に排気して推いてその中につ ルゴンを満たした気密室中で溶接する方法も考学られ ている。

2. 抵抗溶接法

抵抗溶接法は局部加熱であり，また滚接速度も速い ため，一般に大気中で溶接する場合でもシールドはつ 一ク溶接の場合ほどの撖格さを必要とせず，溶接は此 較的容易である。

\section{3. 特殊溶接法}

電子ビーム溶接は第 6 図のように高真空 $\left(10^{-4} \sim 10^{-3}\right.$ $\mathrm{mmHg}$ )中で電子ビームを照射して溶接する方法で, 大気遮蔽の点では理想的な方法といえる。

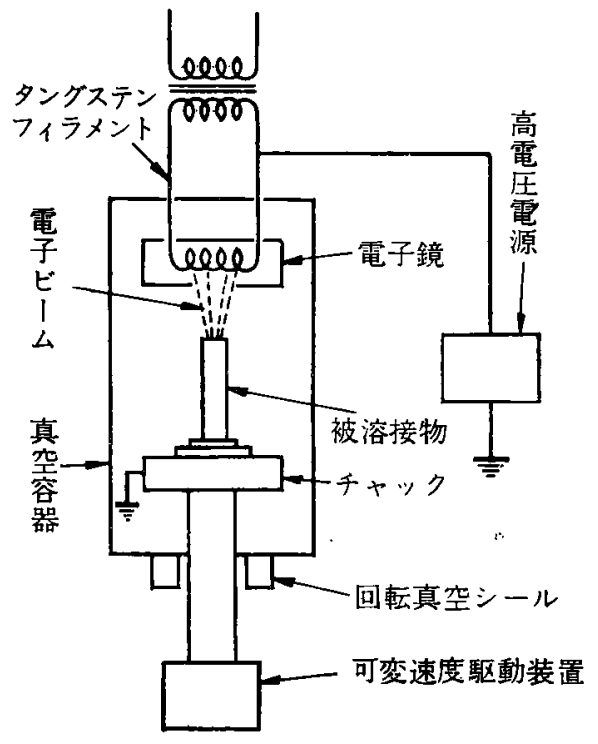

第 6 図 電子ビーム溶接法

また，超音波振動を利用する超音波溶接は溶接温度 は低く、またシールドにも皦格さを必要としないの で，利用される可能性がある。

このほか，特殊な方法としてガス圧着法や，また将 来期待されるすのとしてプラズマフレームの利用があ る。

\section{3 う接法}

一般に，異種金属との融接は不可能であるために， 異種金属との接合法として重要である。イナートガス や高真空の炉中うう接，誘導万う接の的，大気中で 
の抵抗ろう接,超音波ろう接などがある。

\section{1. 施エ上の注意}

シールドは単にフーク発生部を大気から遮断するだ けでなく，高温(約 $500^{\circ} \mathrm{C}$ 以上)の部分はすべてこれを シールドする。たとえばイナートアーク溶接では，シ 一ルドの範囲について第7图のような条件す提案され ており，第8図はシールド要領の1例である。また， ガスの流量には適量があり，それを超えるとかえって アーク雾囲気を搪乱してアークを不安定にしたり， るいは空気のまき込灰を生ずることがあるから注意を 要する。シールドが適正であれば第 3 表の上うに気密 室外であっても，気密室溶接に匹敵するよい結果が兄 られている。ちろんシールドの完全な点では気密室 型式の溶接法がすぐれている。品物が大きくて気密室 を設備することが困難な場合には，ビニール製のカバ 一で溶接部をお战い，その周囲を押えてその中で溶接 する方法るある。また，大気污染の防止と結晶粒の粗大 化とを低減するため，銅製の襄当金や押え金具を用い て溶接部の冷却を速めるなどの工夫もされている。

つぎに材料の表面の污れは溶接欠宿の原因になるか ら溶接前の清浄が必要で, 治具類の表面清净も忘れて

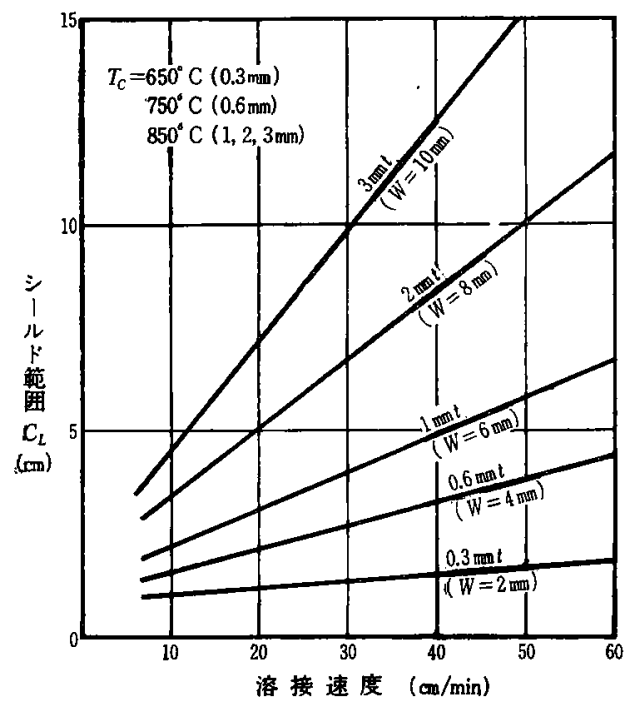

$$
\begin{gathered}
C_{L}=\frac{W}{10 \pi}\left\{\left(\frac{v \cdot W}{10 \alpha}\right)+1.6\right\}\left\{\left(-T_{m} T_{c}^{2}-1\right\}\right. \\
C_{L}: \text { シールドすべき範围 }(\mathrm{cm}) \\
W: \text { ビード幅 }(\mathrm{cm}), \alpha: \text { 熱伝達率 }\left(\mathrm{cm}^{2} / \mathrm{sec}\right) \\
v: \text { 溶接速度 }(\mathrm{cm} / \mathrm{sec}), T_{m}: \text { 融点 }\left({ }^{\circ} \mathrm{C}\right) \\
T_{c}: \text { シールドの必要な最低限の温度 }\left({ }^{\circ} \mathrm{C}\right)
\end{gathered}
$$

第 7 図溶接電極から後部のガスシールド管囲
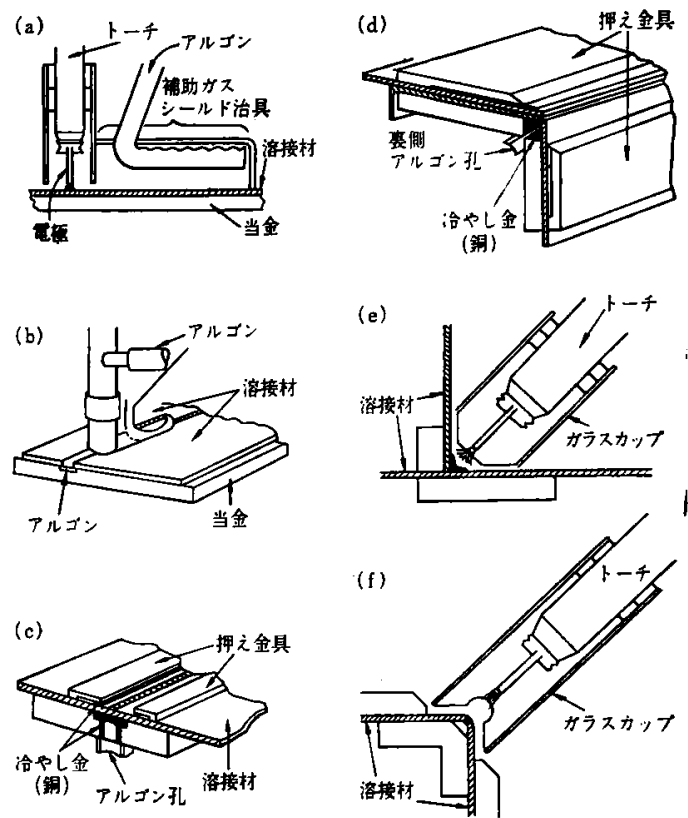

符 8 図 ガスシールド要預例

はならない。厚板の溶接ではできれば各層ごとに清洔 することが望ましい。溶接棒の清净も母材と同様であ るが，一般に母材よりる純度の高いものが望まてい。 溶接棒は高温アーク中に送り込まれるために，もっと 舟污染されやすい状態にあり，溶接中シールドガス中

\begin{tabular}{|c|c|c|c|c|c|c|}
\hline \multirow{2}{*}{ 溶接方法 } & \multirow{2}{*}{ 材 種 } & \multirow{2}{*}{$\begin{array}{l}\text { 板厚 } \\
(\mathrm{mm})\end{array}$} & \multirow{2}{*}{$\begin{array}{c}\text { 表曲げ } \\
\left({ }^{\circ}\right)\end{array}$} & \multirow{2}{*}{$\begin{array}{c}\text { 串曲げ } \\
\left(\begin{array}{c}0 \\
0\end{array}\right)\end{array}$} & \multicolumn{2}{|c|}{$\begin{array}{l}ヒ ゙ 一 ト ~ \\
\text { 綐曲 げ }\end{array}$} \\
\hline & & & & & $\begin{array}{c}\text { 表曲计 } \\
\left({ }^{\circ}\right)\end{array}$ & $\begin{array}{c}\text { 裏曲! 活 } \\
\left({ }^{0}\right)\end{array}$ \\
\hline $\begin{array}{l}\text { 補助ガス } \\
\text { あり }\end{array}$ & $\begin{array}{l}\text { ジルカロ } \\
\text { イ-2 }\end{array}$ & $\begin{array}{l}1 \\
2\end{array}$ & $\begin{array}{r}120 \\
90\end{array}$ & $\begin{array}{r}140 \\
90\end{array}$ & $\begin{array}{l}140 \\
110\end{array}$ & $\begin{array}{l}150 \\
120\end{array}$ \\
\hline 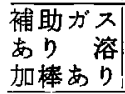 & 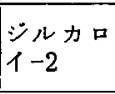 & $\begin{array}{l}1 \\
2\end{array}$ & $\begin{array}{r}110 \\
80\end{array}$ & $\begin{array}{r}110 \\
90\end{array}$ & $\begin{array}{r}120 \\
90\end{array}$ & $\begin{array}{l}120 \\
120\end{array}$ \\
\hline $\begin{array}{l}\text { 補助ガ ス } \\
\text { なし 溶 } \\
\text { 加棒な }\end{array}$ & $\begin{array}{l}\text { ジルカロ } \\
\text { イ-2 }\end{array}$ & $\begin{array}{l}1 \\
2\end{array}$ & $\begin{array}{r}110 \\
70\end{array}$ & $\begin{array}{r}120 \\
90\end{array}$ & $\begin{array}{r}110 \\
90\end{array}$ & $\begin{array}{l}120 \\
100\end{array}$ \\
\hline 気 密 室 & 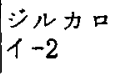 & $\begin{array}{l}1 \\
2\end{array}$ & $\begin{array}{r}170 \\
90\end{array}$ & $\begin{array}{r}170 \\
90\end{array}$ & $\begin{array}{r}180 \\
80\end{array}$ & $\begin{array}{r}170 \\
80\end{array}$ \\
\hline
\end{tabular}
から外出すようなことがあってはならない。チニー ブの溶接では，チューブの内面にもガスさ流すのが上 い。

第 3 表 曲げ試験結果 (TIG)

溶接前には一般に機械的研磨で表面皮膜を除去し， 適当な脱脂を行なった後，酸洗い(3〜7\% $\mathrm{HF}$ と 40〜 50 $\% \mathrm{HNO}_{3}$ の混酸で約 30 秒，その後流水で水洗)するの がよい。

気孔は発生しないのがふつうてある。しかし，表面 
の污れている場合とか，溶接入熱条件が適正を欠く場 合などには，溶接境界線に発生することがある。

\section{IV. 溶接部の諸性筫}

シルコニウムは継手のクリーニンク゚とシールドに注 意すれば溶接性は良好で，一般に適正条件で溶接すれ
ば強さや伸びが素材に匹敵する継手が得られる。第 4 表は大気中でアルゴンフーク溶接する場合の溶接条件 の 1 例である。開先の形状扰よび寸法は大体第 9 図の よ5なるのが使われる。また気密室中で溶接する場合 には, 気密室の初期真空度は $10^{-1} \mathrm{mmHg}$ 以下であれば よい。板厚が 0.08 ”下の突合わせ溶接では一般に溶

第 4 表 ジルコニウム薄板の空気中でのアルゴンアーク溶接条件 (DC. SP)

(ジルカロイー2る同じ条件でよい)

\begin{tabular}{|c|c|c|c|c|c|c|c|c|}
\hline \multirow{2}{*}{$\begin{array}{l}\text { 板 厚 } \\
(\mathrm{mm})\end{array}$} & \multirow{2}{*}{$\begin{array}{l}\text { 溶加棒 } \\
\text { 直 径 } \\
(\mathrm{mm})\end{array}$} & \multirow{2}{*}{$\begin{array}{c}\text { タングステ } \\
\text { ソ電極直径 } \\
(\mathrm{mm})\end{array}$} & \multirow{2}{*}{ 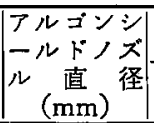 } & \multicolumn{2}{|c|}{ アルゴン流量 } & \multirow{2}{*}{$\begin{array}{c}\text { 溶接電流 } \\
\text { (A) }\end{array}$} & \multirow{2}{*}{$\begin{array}{l}\text { 溶接速度 } \\
(\mathrm{mm} / \mathrm{min})\end{array}$} & \multirow{2}{*}{ 備 } \\
\hline & & & & $(l / \mathrm{min})$ & 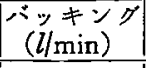 & & & \\
\hline 0.50 & - & 1.6 & 9.5 & 6.3 & 2.3 & 40 & 1270 & 機械溶接 \\
\hline 0.75 & - & 1.6 & $" \prime$ & " & " & 45 & 一 & 手 溶 接 \\
\hline 1.00 & - & 2.4 & 12.7 & $\prime \prime$ & $\prime \prime$ & 60 & 635 & 機械溶接 \\
\hline 1.50 & - & 3.2 & $\prime \prime$ & 7.2 & " & 55 & - & 手溶接 \\
\hline 1.50 & - & $" l$ & "I & $" l$ & $" \prime$ & 80 & 635 & 機械溶接 \\
\hline 1.50 & 1.25 & $\prime \prime$ & 15.9 & " & $" \prime$ & 50 & - & 手 溶 接 \\
\hline 2.30 & 2.00 & "l & $" l$ & " & $" \prime$ & 60 & - & $" \prime$ \\
\hline 3.00 & "l & "l & $\prime \prime$ & $\prime \prime$ & "1 & 94 & - & $" 1$ \\
\hline 3.80 & "l & 4.8 & $" 1$ & $" \prime$ & $\prime \prime$ & 140 & - & " \\
\hline 4.70 & $" \prime$ & $\prime \prime$ & " & " & " & 165 & $\rightarrow$ & $" \prime$ \\
\hline
\end{tabular}

加棒は用いない。また TIG 溶接の溶接電源は交流で なく，直流正極性が多い。

第 5 表は電子ビーム溶接条件例を示す。

溶接カバーを用いた時の溶接部のカタサは，空気中 のものに比してかなり低く、これを気密室中で溶接す るとさらに幾分低くなり, 熱影響部とほとんど同程度 となる。
第10図はジルカロイ-2 の溶接部のカタサ分布を示 したものである。

ジルコニウム溶接部の組織は典型的なウィッドマン 組織である。

また，第 6 表はジカロイー2 の溶着金属の分析值 であるが，大気による污染は全く認められない。電子 ビーム溶接ではすずが多少減少するよ5である。

第 5 表 ジルコニウム、ジルカロイ -2 板の電子ビーム溶接条件例

\begin{tabular}{|c|c|c|c|c|c|c|c|c|}
\hline \multirow{2}{*}{$\begin{array}{l}\text { 板 厚 } \\
(\mathrm{mm})\end{array}$} & \multirow{2}{*}{$\begin{array}{c}\text { 加速電圧 } \\
(\mathrm{kV})\end{array}$} & \multicolumn{3}{|c|}{ 溶 } & 速 & \multicolumn{2}{|l|}{$(\mathrm{cm} / \mathrm{min})$} & \multirow[b]{2}{*}{100} \\
\hline & & 10 & 20 & 30 & 40 & 50 & 70 & \\
\hline \multirow{3}{*}{0.3} & 15 & - & $\mathrm{mA}^{2 \sim 5}$ & $\stackrel{\mathrm{mA}}{3 \sim 6}$ & $\stackrel{\mathrm{mA}}{4 \sim 7}$ & $\underset{5 \sim 8}{\mathrm{~mA}}$ & - & - \\
\hline & 20 & - & - & - & - & $I \sim 2$ & $1 \sim 3$ & $1.5 \sim 3.5$ \\
\hline & 30 & - & - & 一 & - & $2.5 \sim 4$ & $3.5 \sim 5$ & - \\
\hline \multirow{3}{*}{0.6} & 20 & - & $3 \sim 6$ & $4.5 \sim 8$ & $6 \sim 9$ & $8 \sim 12$ & $12 \sim 15$ & - \\
\hline & 30 & - & - & - & - & $3 \sim 6$ & $6 \sim 10$ & $11 \sim 15$ \\
\hline & 40 & - & - & - & - & - & $4 \sim 6$ & - \\
\hline \multirow{3}{*}{1.0} & 30 & $5 \sim 8$ & $7 \sim 10$ & $9 \sim 12$ & $11 \sim 14$ & $13 \sim 16$ & - & - \\
\hline & 40 & - & $6 \sim 9$ & $8 \sim 11$ & $9 \sim 12$ & $11 \sim 14$ & $14 \sim 17$ & - \\
\hline & 50 & - & $4 \sim 6$ & $5 \sim 8$ & $6 \sim 9$ & $8 \sim 11$ & $11 \sim 14$ & $15 \sim 19$ \\
\hline \multirow{3}{*}{2.0} & 30 & $15 \sim 19$ & - & - & - & - & - & - \\
\hline & 40 & $11 \sim 13$ & $13 \sim 17$ & $16 \sim 20$ & - & - & - & - \\
\hline & 50 & $9 \sim 12$ & $11 \sim 15$ & $13 \sim 17$ & $15 \sim 19$ & - & - & - \\
\hline
\end{tabular}




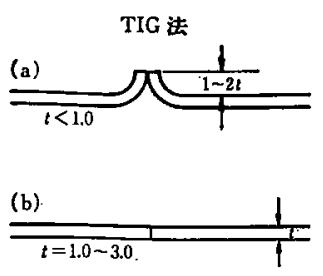

(c)

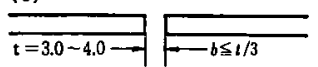

(d)
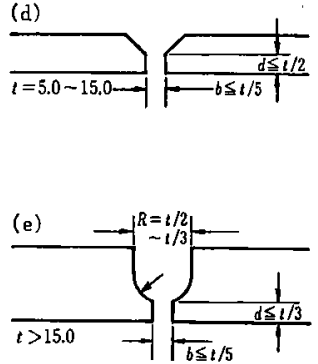

第 9 図開先の形状および寸法

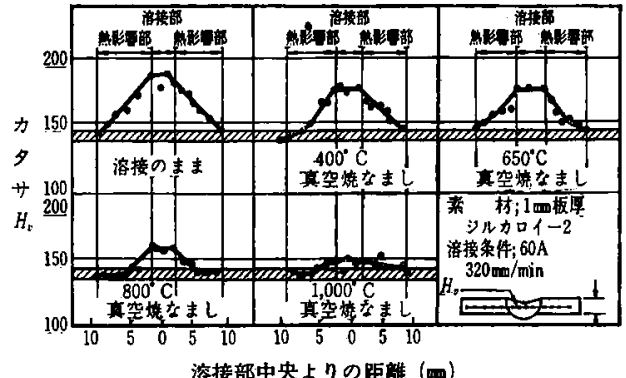

第10図 溶接のままおよび真空焼なむし後の 溶接継手のカタサ分布 (TIG)

第 6 表 ジルカロイー2 溶着金属の分析値

\begin{tabular}{|c|c|c|c|}
\hline 元 & \begin{tabular}{|l} 
電子ビーム \\
溶
\end{tabular} & 溶 ${ }^{\mathrm{TIG}}$ 接切 & 素 \\
\hline $\begin{array}{l}\mathrm{O}_{2}(\mathrm{ppm}) \\
\mathrm{N}_{2}(\mathrm{ppm}) \\
\mathrm{Sn}(\%) \\
\mathrm{Fe}(\%) \\
\mathrm{Cr}(\%) \\
\mathrm{Ni}(\%) \\
\quad\left(H_{v}\right)\end{array}$ & $\begin{array}{c}675,810 \\
11,34 \\
0.94 \\
0.069 \\
0.081 \\
0.079 \\
170 \sim 180\end{array}$ & $\begin{array}{c}730 \sim 780 \\
10 \sim 24 \\
1.46 \\
0.131 \\
0.110 \\
0.079 \\
160 \sim 170\end{array}$ & $\begin{array}{c}735 \\
12 \\
1.40 \\
0.136 \\
0.113 \\
0.061 \\
140\end{array}$ \\
\hline
\end{tabular}

$\dagger$ 電子ビーく颁接：真空度 $(0.6 \sim 5) \times 10^{-5}$ Torr, $50 \mathrm{kV}$ ， $11 \sim 15 \mathrm{~mA}, 20 \mathrm{~cm} / \mathrm{min}$

t† TIG 溶接： $99.99 \%$ Ar, 760 Torr, 7 8 V, 80 90 A, $16 \mathrm{~cm} / \mathrm{min}$

\section{1. 溶接部の機械的性腯}

ジルカロイー2の単層溶接部の引張り試験の結果を 第11図に示すが，破断はすべて非熱影響部の素材部で 発生している。

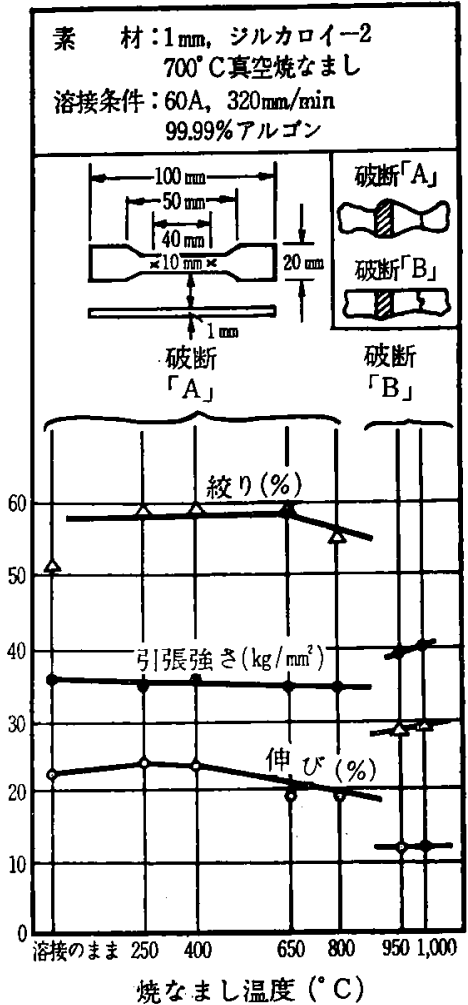

第11図烧ななと常温引張特性(TIG)

また，第 7 表はジルコニウム溶着金属の機械的性質 の比較であるが，TIG溶接と電子ビーム溶接とでは引 張り,曲げ特性にほとんど差はない。

第 7 表 ジルュニウム溶着金属の機械的性質

\begin{tabular}{|c|c|c|c|c|}
\hline \multirow{2}{*}{ 溶接 法 } & \multicolumn{3}{|c|}{ 引 張 試 殹 } & \multirow{2}{*}{$\begin{array}{l}\text { 曲げ試験 } \\
\text { 割れ発生 } \\
\text { 角 }\end{array}$} \\
\hline & $\begin{array}{l}\text { 引張強さ } \\
\left(\mathrm{kg} / \mathrm{mm}^{2}\right)\end{array}$ & $\begin{array}{c}\text { 筊 } \\
(\%)^{n}\end{array}$ & $\begin{array}{c}\text { 伸 び } \\
(\%)\end{array}$ & \\
\hline 材 & $29 \sim 34$ & $48 \sim 53$ & $33 \sim 40$ & 61 \\
\hline $\begin{array}{l}\text { TIG 溶接 } \\
\text { (気密室) }\end{array}$ & $32 \sim 36$ & $47 \sim 50$ & $18 \sim 23$ & 67 \\
\hline $\begin{array}{l}\text { 電子ビ一ム溶 } \\
\text { 接 }\left(10^{-5} \text { Torr }\right)\end{array}$ & $30 \sim 32$ & $47 \sim 54$ & $18 \sim 22$ & 69 \\
\hline
\end{tabular}

曲げ試験はジルコニウム関係では，その靮性度の比 較に非常に多く用いられている。ジルカロイ -2 の 3.2 $\mathrm{mm}$ 板厚の単層溶接部の曲げ試験結果を第 8 表に示す。 これによればジルカロイー2 の单層溶接部の曲げ靱性

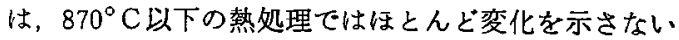
が, $870^{\circ} \mathrm{C} よ り$ 水焼入れ寸ることによってもっとす改 普される。逆にこの温度より空冷と炻泠したものは,

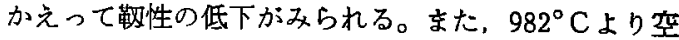
冷と炉冷したものはもらろんであるが，水焼入れした ものも溶接のままに比してわずかに低下している。 以上により，ジルカロイー 2 の溶接部は $870^{\circ} \mathrm{C}$ より 
水冷するにとによって析出を阻止し，良好な鞄性が得 られる。

第 8 表 ジルカロイ -2 溶接部単層溶接部の 熱処理後の長手曲げ試駼結果(TIG)

\begin{tabular}{|c|c|c|c|c|}
\hline 条 & 件 & 最小曲げ半径 & $\begin{array}{c}\text { 伸 び } \\
(\%)\end{array}$ & 割れ発生源 \\
\hline 溶接の & まま & $21 / 2$ & 17 & 溶接部々素材 \\
\hline \multicolumn{5}{|c|}{$1,200^{\circ} \mathrm{F}$ で熱処理 } \\
\hline 水 & 冷 & $31 / 2$ & 13 & 溶 接 部 \\
\hline 空 & 冷 & 3 & 14 & 溶接部と素材 \\
\hline 焐 & 冷 & $21 / 2$ & 17 & 溶 接 部 \\
\hline \multicolumn{5}{|c|}{$1,400^{\circ} \mathrm{F}$ で熱処理 } \\
\hline 水 & 冷 & $21 / 2$ & 17 & \multirow{3}{*}{$\begin{array}{l}\text { 溶接部と絮材 } \\
\text { 溶 接 部 } \\
\text { 溶接部, } \\
\text { HAZ と紊材 }\end{array}$} \\
\hline 空 & 冷 & $31 / 2$ & 13 & \\
\hline 炉 & 冷 & 3 & 14 & \\
\hline \multicolumn{5}{|c|}{$1,600^{\circ} \mathrm{F}$ で熱処理 } \\
\hline 水 & 冷 & 2 & 20 & $\begin{array}{l}\text { 溶接部 } \\
\text { HAZ } \text { と素材 }\end{array}$ \\
\hline 空 & 冷 & 6 & 8 & 溶 接 部 \\
\hline 炉 & 冷 & 6 & 8 & 溶 接 部 \\
\hline \multicolumn{5}{|c|}{$1,800^{\circ} \mathrm{F} て ゙$ 熱姏理 } \\
\hline 水 & 冷 & 3 & 14 & 溶接部と素材 \\
\hline 空 & 冷 & 4 & 11 & 溶＼cjkstart接＼cjkstart部 \\
\hline 炉 & 冷 & 4 & 11 & 溶 接 部 \\
\hline
\end{tabular}

また，第12図は溶接のままと，各種真空焼なまし後 の曲げ試験結果で，ビードの裏側を溶加棒なしで数回

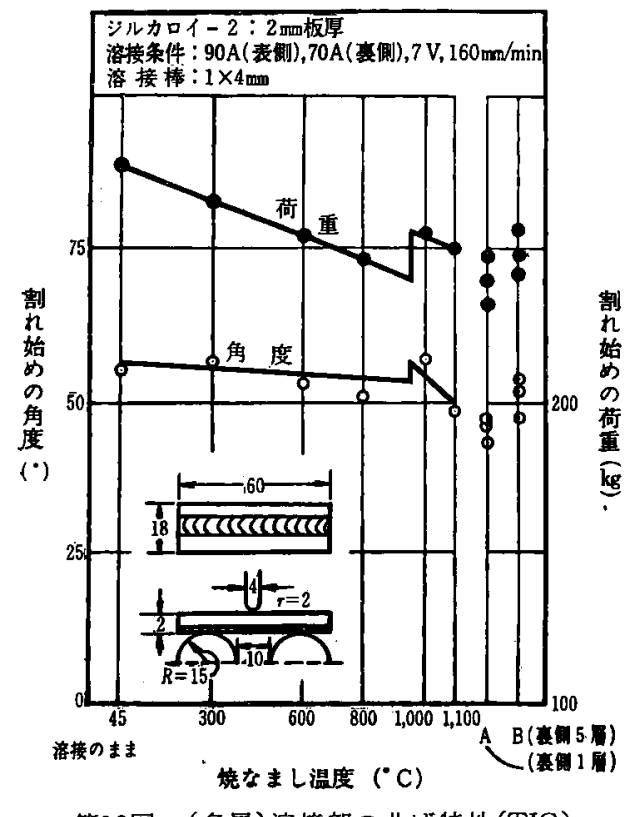

第12図（多層) 溶接部の曲げ特性(TIG）
にわたりビード置きをした時の曲げ特性す同時に示し てある。これは多層溶接した時とほは類似の条件とな るが，析出によるぜい化は僅かなようである。

また，第 9 表は $1 \mathrm{~mm}$ 板厚のジカロイー2 の溶接 継手のラプチャ一試駼結果であるが，破断強さは素材 上り $4 \sim 5 \mathrm{~kg} / \mathrm{mm}^{2}$ 高い。試験後の破断は，溶接部お よび熱影響部にははとんど伸びがみられずすへで䒺 材部で破断している。

第 9 表 ジルカロイー2の各時間ラプチャ一強度 $\left(\mathrm{kg} / \mathrm{mm}^{2}\right)(\mathrm{TIG})\left(316^{\circ} \mathrm{C}\right)$

\begin{tabular}{|c|c|c|c|c|c|}
\hline 試 & 験 & $10 \mathrm{hr}$ & $100 \mathrm{hr}$ & $1,000 \mathrm{hr}^{\mathrm{I}}$ & $10,000 \mathrm{hr}^{\dagger}$ \\
\hline 素材 & ジルカロイ -2 & 19.8 & 19.4 & 19.2 & 19.0 \\
\hline 継手 & ジルカロイ -2 & 23.7 & 23.3 & 23.0 & 22.6 \\
\hline
\end{tabular}

つぎに、ジルカロイー2 溶着金属 (6mm厚)の衝撃特 性を第13図に示す。試料はいずれる溶接のままである が，溶接部の衛慗值は素材に比してかなり低い。また 電子ビーム溶接は TIG 溶接に比べてかなりよい結果 が得られている。この場合の溶着金属の水素分析值は 第10表からわかかると扰り，電子ビーム溶接ではその 量がかなり低くなっておりここれが衝撃特性向上の一 因と招すわれる。

また，原子然料被覆棒模型の破壊例がある。これは 第11表の上5なエンドプラグ溶接例があるが，耐圧試 験結果でる溶接部は健全であり，適正な溶接条件で行

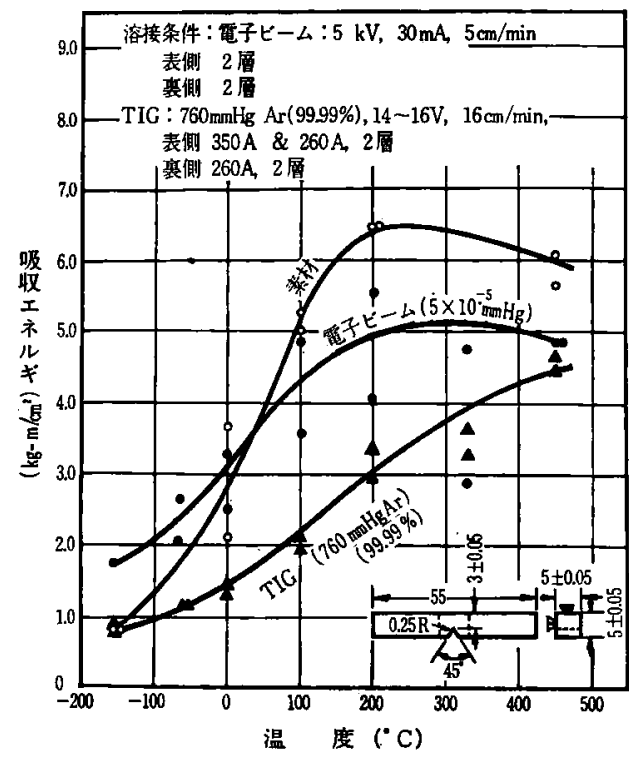

第13図 ジルカロイー2 の衝媻特性( $6 \mathrm{~mm}$ 厚) 
第10表 溶着金属の水素分析 (6mm 厚)

\begin{tabular}{|c|c|c|}
\hline 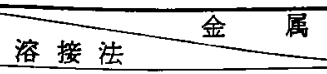 & $\begin{array}{l}シ ル コ=ウ \\
\wedge(\mathrm{ppm})\end{array}$ & $\begin{array}{l}\text { チタン } \\
(\mathrm{ppm})\end{array}$ \\
\hline $\begin{array}{c}\text { 電子ビーム溶接 } \\
\left(\begin{array}{l}5 \times 10^{-5} \text { Torr, } 50 \mathrm{kV}, \\
30 \mathrm{~mA}, 5 \mathrm{~cm} / \mathrm{min}\end{array}\right)\end{array}$ & $\left.\begin{array}{l}1 \\
0.9 \\
0.9\end{array}\right\} \begin{array}{r}\text { 平均 } \\
0.9\end{array}$ & $\left.\begin{array}{l}11 \\
11 \\
10\end{array}\right\} 11$ \\
\hline $\begin{array}{c}\text { TIG 溶接 } \\
\left(\begin{array}{l}99.99 \% \text { Ar, } 760 \text { Torr, } \\
320 \mathrm{~A}, 15 \mathrm{~V}, 16 \mathrm{~cm} / \mathrm{min}\end{array}\right)\end{array}$ & $\left.\begin{array}{l}6 \\
6 \\
6\end{array}\right\}$ & $\left.\begin{array}{l}12 \\
11 \\
10\end{array}\right\} 11$ \\
\hline 素 & $\left.\begin{array}{l}6 \\
6 \\
6\end{array}\right\}$ & $\left.\begin{array}{l}11 \\
11 \\
10\end{array}\right\} 11$ \\
\hline
\end{tabular}

なえば，充分な性能が得られるるのと考える。

な拉，ジルコンウムは適当な表面処理を施し，気密 室中で溶接するときは，へリウム漏れ試験に合格し， またX線試験で合格したるのは，すべて漏れ試験にる 合格するといわれている。

\section{2. 溶接辚手の化学的特性}

\section{（1）酸に対する耐食性}

鉄を合む濃盐酸 $(1 \mathrm{~g} / l$ の鉄を含む)に，室温で 24 時 間浸漬する方式と，鹰食状態をさらに増加するために 液中で試験片を30 r.p.m.で回轱させる方法の両方を行 なった例によると，溶接ビードと熱影響部は母材より 明らかに耐食性が強い上うである。この結果は溶接に

第11表 ジルカロイー2パイプエンドプラグの溶接例

\begin{tabular}{|c|c|c|c|c|c|}
\hline 溶 接 法 & 溶 接 電 流 & 電 $(\mathrm{V})^{\text {压 }}$ & 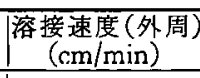 & 回 & 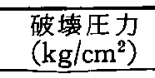 \\
\hline $\begin{array}{l}\text { TIG 溶接 } \\
\text { （気密室） }\end{array}$ & $\left.\begin{array}{ll}\text { スタート : } 90 \mathrm{~A}(1 \mathrm{sec}) \\
\text { 中 } & \text { 間 : } 60 \mathrm{~A} \\
\text { 終 } & \text { 端 }: 10 \mathrm{~A}(3 \mathrm{sec})\end{array}\right\}$ & 8.5 & 16 & 1.5 & 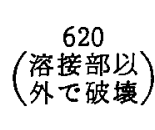 \\
\hline $\begin{array}{l}\text { 電子ビーム } \\
\text { 溶 }\end{array}$ & $\begin{array}{r}12 \mathrm{~mA} \text { (1.5 回転後 } \\
\text { 電流潮滅) }\end{array}$ & $40 \times 10^{3}$ & 30 & 1.8 & $\left(\begin{array}{c}615,620 \\
(\text { 溶接部以 } \\
\text { 破壊 }\end{array}\right)$ \\
\hline
\end{tabular}

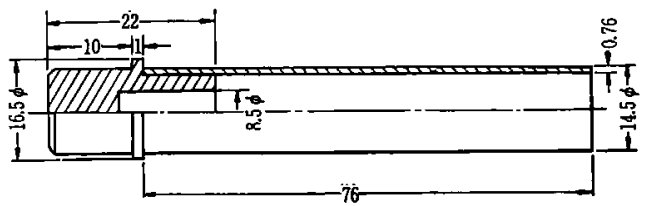

使用した電流の種類や溶接方法にはあまり関係がな い。

溶接部と熱影響部が母材より耐食性のよい理由とし ては，溶接中に炭䒺が燃焼するため炭㨞量が低くなる ことに影響するのではないかといら考え方がある。耐 食性に影響するすつは雾围気ガスの表面吸収度槕よび 炭素と鉄の分布扰よび組織の差によると考えられてい る。

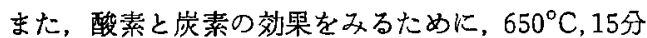
の焼鈍を各種雾围気中で行ない，それを塩酸-塭化第 二鉄中で72時間浸漬試験した結果によれば，炭素の增 加か腐食を增加させる原因ではなざううであるし，酸 素は保萑膜をつくるとる報じている。

（2）高温高圧水に対方る耐食性

ジルカロイー2 溶接部の高温高圧水に対与る耐食性

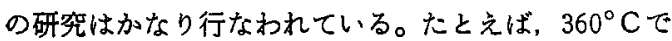
245日間の高温水中の腐食試験によれば，空気中のTIG 法によるすのも気密室中のものるほとんど差がなく， 母材と溶接継手はほぼ同一であったといら報告があ
る。しかし一方， $325^{\circ} \mathrm{C}, 1750 \mathrm{psi}$ の蒸留水中て腐食試 験を行なった結果によれば，空気中でTIG溶接を行な ったすのは，7日間の試験ですでに“Breakaway”を おこした。また気密室中で溶接したものでも，初期真 空度を $4.5 \times 10^{-2} \mathrm{mmHg}$ にしたものは 7 日間の試験で やはり熱影響部之溶接部の境界に白い酸化物 $\mathrm{ZrO}_{2}$ か 発生し"Breakaway"を抗こした。しかし初期真空度

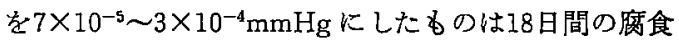
試験でるは任とんど腐食しなかったと報告しているすの すある。また，溶接継手はショットブラストと酸洗い すれば腐食量は減少するようである。

また，第14図はジルカロイー2 の TIG 溶接 の溶着金 属の, 高温高圧水 $\left(320^{\circ} \mathrm{C}\right)$ 儿上る腐食試験結果のI例 であるが，気密室中の溶接とか，適正な補助ノズルを 用いる場合儿は良好な耐食性が得られる。ふつう， ズル型式のるのは耐食性は劣り，結果は非常にムラが 多い。また，腐食後の引張り試験結果では，外観ある いは重量変化から考えるほど腐食は強さに影響してい ないが，気密室中拉よびトレーラ付きのものはすぺて 


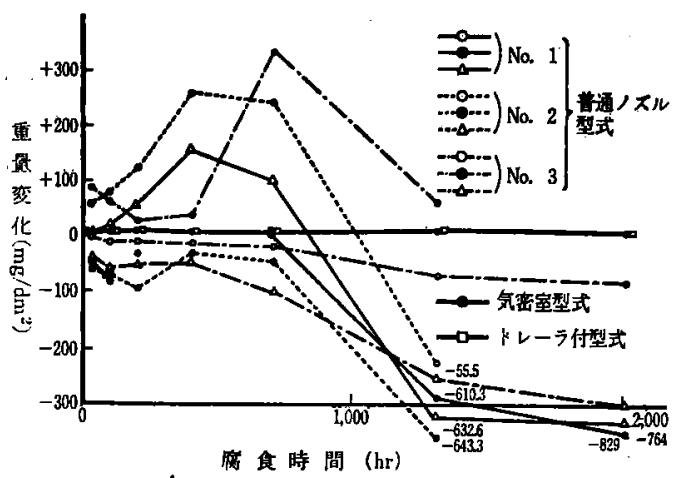

第14図 シ ジカロイ-2(板厚 $1 \mathrm{~mm}$ )溶着 金属部の $320^{\circ} \mathrm{C}$ の高温高圧水に よる麻食試験結果(TIG)

素材で破断しているに反し，ふつ5のノズル型式のも のは溶接による污染のために，溶接部で破断する場合 るある。

また，第15図は高温高圧循環水 $\left(300^{\circ} \mathrm{C}, 110\right.$ 気圧，流 速約 $7 \mathrm{~m} / \mathrm{sec}$ ）による動的腐食試験結果でおるが，静水

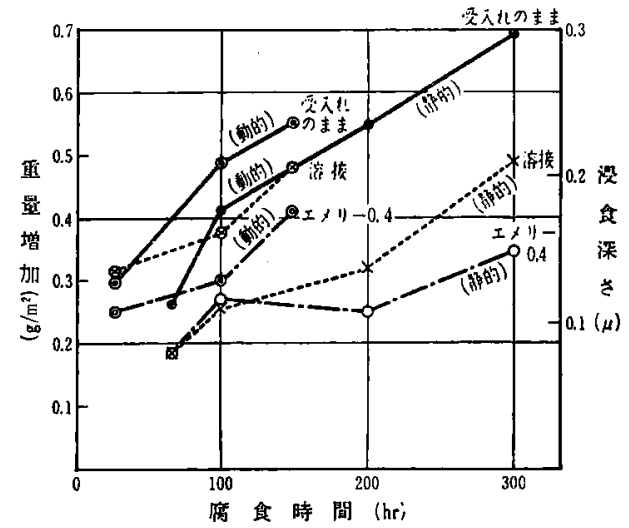

第15図 ジルロイ-2(板嬮 $1 \mathrm{~mm}$ ) の $300^{\circ} \mathrm{C}$ の滈温高压水による静的招よび動的 腐食試缓結果(TIG)

第12表 高温高圧水による腐食試験(シルカロイー2)

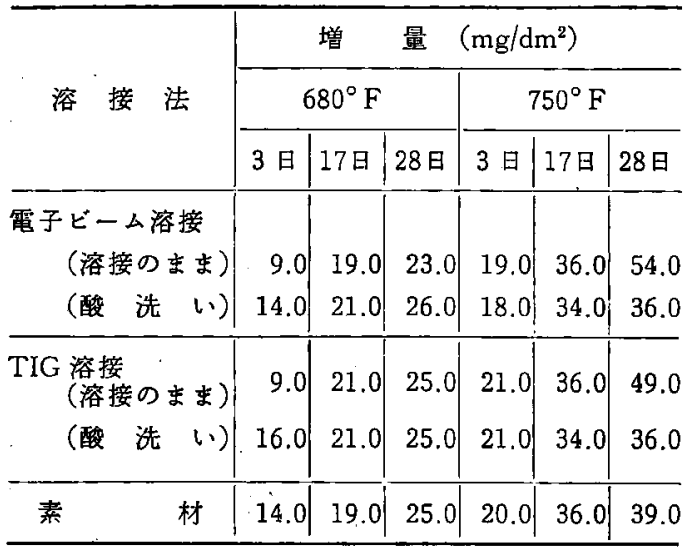

中よりす而食性はやや劣るようである。溶接法による 耐食性の比較を第12表に示しているが，電子ビーム， TIG 溶接とすに素材に匹敵する性能をるっている。

また，国産のジルコニウムスポンジではチッ素が少 ないといわれているが，この場合にはすずは1\%であ っても，溶接部の耐食性には悪影響がないことが確認 されている。

\section{V.その他の溶接法}

\section{1. 抵抗溶接}

シルコニウムとその合金の抵抗溶接は比較的容易て ある。しかも局部加熱で冷却速度が極端に速いために 大気による污染も問題とならない。また溶接部が多少 変色してる，これをショットブラストと酸洗いすれば 高温水中の耐食試験では支障ないよ5である。また， 溶接部には気孔その他の溶接欠陷は全然見当らず，シ ーム溶接では気密性のある溶接部が得られるものと考 える。

第13表はジルコニウム, ジルカロイー2の適正スポッ ト溶接条件の 1 例であるが，これらの試料はいずれる 1300 時間, $320^{\circ} \mathrm{C}$ の高温水の腐食試験において子充分 健全であった。

第13表 ジルコニウムおよびジルカロイー2 のスポット溶接

\begin{tabular}{|c|c|c|c|c|c|c|c|}
\hline \multirow[b]{2}{*}{ 材 料 } & \multirow{2}{*}{$\begin{array}{c}\text { 坂厚 } \\
(\mathrm{mm})\end{array}$} & \multicolumn{3}{|c|}{ 溶 接条件 } & \multirow{2}{*}{$\begin{array}{l}\text { ナゲッ } \\
\text { 卜直径 } \\
(\mathrm{mm})\end{array}$} & \multirow[b]{2}{*}{$\begin{array}{l}\langle ほ ゙ み \\
(\mathrm{mm})\end{array}$} & \multirow{2}{*}{$\begin{array}{l}\text { 引張せ } \\
\text { ん断强 } \\
\text { さ } \\
(\mathrm{kg})\end{array}$} \\
\hline & & \multicolumn{2}{|c|}{ 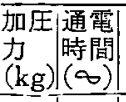 } & $\begin{array}{l}\text { 電流 } \\
\text { (A) }\end{array}$ & & & \\
\hline \multirow{4}{*}{$\begin{array}{l}シ ゙ ル コ \\
=ウ ム\end{array}$} & 0.7 & 230 & 5 & 8,500 & 3.5 & 0.06 & 500 \\
\hline & 1.0 & 300 & 6 & 10,000 & 5.0 & 0.09 & 700. \\
\hline & 1.6 & 420 & 9 & 13,000 & 7.0 & 0.15 & 1,000 \\
\hline & 2.2 & 550 & 12 & 16,000 & 7.6 & 0.22 & 1,500 \\
\hline \multirow{4}{*}{ 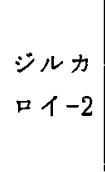 } & 0.7 & 230 & 5 & 8,500 & 3.8 & 0.06 & 600 \\
\hline & 1.0 & 300 & 6 & 10,000 & 5.2 & 0.09 & 800 \\
\hline & 1.6 & 420 & 9 & 13,000 & 7.0 & 0.13 & 1,800 \\
\hline & 2.2 & 560 & 12 & 16,000 & 8.0 & 0.17 & 3,000 \\
\hline
\end{tabular}

\section{2. ろう接}

純ジルコニウムと銀をたは銅のろう接は，真空中ま たはイナートガス中で行な 5 と容易に接着するようて ある。しかし，銅または銅合金のろう付けに，過剩の 銀万らを用いるとジルコニウムが非常に多く食われる. ことが知られている。

30 種類のろう材で, ジルカロイー2 ど5しをイナー トガス雾囲気中で溶㓮を用いずに接着し、・それを 360 
○C の加圧水中に 1,200 時間浸清した結果によれば，接 合部にギャップのないときにはろう材に Cu-20Pd-31 In, Ni-3.4P, Zr-5Be，またギャップをつけたときには Cu-20Pd-3 In, Ni-20Pd-10Si, Ni-30Ge-13Cr, Zr-5Be, $\mathrm{Zr}-10 \mathrm{Fe}-10 \mathrm{Cr}$ のるのはほとんど腐食をおこさなかっ たもようである。

しかし，万う接は今後に多くの問題を残しており， 接着性のほかに原子师用には熱中性子吸収の少ない万 万材が必要で，根本的な研究が必要である。

以上基礎的諸問題についてその概要を述べたか，ま ギまだ研究すべき点めるいは溶接施工上改良すべき点
るないでるない。ともあれ本報がジルコニウム溶接開 発に関して一助となれば幸いである。

なお，本資料作製に当り溶接協会ならびに燃料被覆 管耐圧試験委員会資料を多く引用させていただいた。

$$
\text { （1962年 12月27日 受理） }
$$

日本溶接協会: “原子梮用ジルコニウム扰よびマク ネシウム合金の溶接に関する研究”, (昭和 34 年度科学 技術庁原子力平和利用補助金交付研究)，(昭36.2).

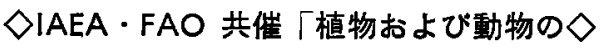
害虫制御におけるラジオアイソトーブ および放射線の利用および応用シンボ ジウム」

$$
\text { 論 文 募 集 }
$$

IAEA・FAO 共催の標記シンポジゥムが下記により 開催され，論文提出捄よび会誐参加者を募集している。

1. 1963年 4 月22〜26日 (於了テネ)

2. 討議議題
(a) 昆虫生態学（分布，移楼抒よびライフ・サイクル）
(b) 殺虫剤(ラベリング，応用,吸収、トランスロケーション，

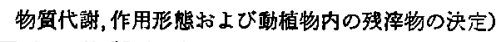
(c) 昆虫の物質代謝

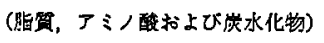
（d）尼虫扰よび他の節足動物に対する照射效果 (致死およびひん死效果，乫然变暴，害虫の制御㧍上び 䋓隇のための消毒および去势技術の使用)

3. 応莫期限

○フプストラクト(英文?部、和文 1 部, 350呚以内) 1 月 5 日 (金)

○本論文 (英文 5 部) 2 月15日 (金)

O参加申込 (所定書式で3部) 1 月 5 日(土)

\section{$\diamond I A E A\lceil$ 動力炉運転経験に〉 ついての科学会議」 論 文 募 集}

IAEA 主催の標記会誘が下記により開催され, 論文 提出扎よび会議参加者を募集している。

1. 1963年 6 月 $4 \sim 10$ 日 (於ロィーン)

2. 討議議題
(a) 政府の電力計画に関連して原子力発電所につ いて得た経臨の概要
(b) 特定の原子力発電所で得た経験
(c) 原子力発電所の人事管理
(d) 原子力発霓所の主要設備にっいての経験
(e) 燃料サイクルならびに燃料の取扱いと管理
(f) 原子力発電コストの実積
(g) 原子力発電計画進展のための経験の活用

3. 応募期限

Oフブストラクト (英文 7 部, 和文 1 部, 350祸以内)

$\begin{array}{ll} & 1 \text { 月31日(木) } \\ \text { O本論文 (英文 5部) } & 3 \text { 月30日(土) } \\ \text { O参加申込 (所定著式で3部) } & 1 \text { 月31日(木) }\end{array}$

4. 提出·連絡先 原子力局 国際協力課 